УДК 351.74:342.922

DOI https://doi.org/10.32841/2307-1745.2019.42-2.18

Єрликов Ю.В., здобувач кафбедри адміністративного та митного права Університету митної справи та фбінансів

\title{
СУДОВИЙ ПОРЯДОК ОСКАРЖЕННЯ РІШЕНЬ, ДІЙ ЧИ БЕЗДІЯЛЬНОСТІ СУБ’ЄКТІВ ВЛАДИ ЩОДО ЗДІЙСНЕННЯ АДМІНІСТРАТИВНИХ ПРОЦЕДУР У СФЕРІ МІГРАЦІЇ
}

\begin{abstract}
Анотація. Наукова стаття присвячена висвітленню судового порядку оскарження рішень, дій чи бездіяльності суб'єктів публічної адміністрації щодо здійснення адміністративних процедур у сфері міграції. Встановлено, що адміністративне оскарження, незважаючи на ознаку факультативності, є важливим етапом адміністративної процедури у сфері міграції. 3 одного боку, оскарження призначене на виявлення й усунення недоліків у практичній процедурній діяльності органів публічної влади у сфері міграції; з іншого - сприяє вдосконаленню самої процедурної моделі вирішення індивідуальних справ у досліджуваній сфері, виявляючи ії дефекти і слабкі місця.

Акцентовано увагу, що законодавче закріплення можливості здійснення оскарження в судовому та адміністративному порядку зумовлює наявність двох форм оскарження - адміністративно-процедурної та адміністративно-процесуальної, що в сукупності створюють гарантійний інструмент захисту прав приватних осіб на громадянство та на свободу пересування й вільний вибір місця проживання.
\end{abstract}

Встановлено, що наявність у Реєстрі за предметом позову та вимогами позивачів справ - №№ 820/4847/17, 815/2412/14, 820/4393/17, 495/8188/16-а тощо - дає змогу вважати проаналізовану справу прикладом типової. I знову ж таки за результатами розгляду наведеного кейс-стаді можна зробити висновок, що в діяльності підрозділів ДМС поширеним явищем $є$ прийняття адміністративних рішень на підставі міркувань дискреції, а не законних приписів; порушення, яких припускаються органи публічної влади в адміністративно-процедурній діяльності, обертаються для фізичних осіб, з боку яких жодних порушень скоєно не було, загрозою втрати законних статусів і прав. Таку ситуацію не можна визнати ефективним прикладом правозастосування в галузі адміністративно-процедурного забезпечення сфери міграції.

Враховуючи значущість захисту прав і свобод фізичних осіб як сторони публічно-правових відносин у досліджуваній сфері, слід визнати можливість судового оскарження рішень, дій чи бездіяльності суб'єктів публічної влади в цій сфері важливою гарантією збереження та відновлення індивідуальних прав. У наведених прикладах судові органи виконали цю захисну функцію; для укріплення цієї тенденції раціонально було б скористатися інструментом зразкової адміністративної справи, що стала однією $з$ найбільш очікуваних новел реформування адміністративного судочинства. Згідно з ч. 22 ст. 4 КАС України зразкова справа - це типова адміністративна справа, прийнята до провадження Верховним Судом як судом першої інстанції для постановлення зразкового рішення; інакше кажучи, за допомогою зразкової справи в судову практику впрова- джується дієвий процесуальний механізм розгляду справ, схожих за сферою та специфікою правовідносин, у яких виник конфлікт, складом сторін і правових норм, якими вони регулюються, за прикладом рішення Верховного Суду в одній із таких справ, тобто за зразковою справою.

Ключові слова: адміністративна процедура, бездіяльність, етапи, дії, імміграція, стадія, судовий порядок, оскарження.

Постановка проблеми. Адміністративно-процесуальна форма оскарження, тобто оскарження дій, рішень чи бездіяльності суб'єктів виконавчої влади в судовому порядку, характеризується особливим процесуальним засобом оскарження адміністративним позовом (на відміну від скарги, притаманної позасудовому оскарженню); віднесенням повноважень щодо захисту прав і законних інтересів фізичних осіб у публічно-правових відносинах до компетенції судових органів; наявністю можливості оскарження й перегляду ухвалених адміністративним судом рішень у судах апеляційної та касаційної інстанцій.

Під час спроб визначити стан та особливості судового оскарження результатів адміністративно-процедурної діяльності органів публічної влади у сфері міграції пропонуємо здійснити розгляд судової практики в зазначеній галузі. Використовуючи дані Єдиного реєстру судових рішень, проведемо змістовий аналіз судових справ, де відповідачем виступає центральний орган виконавчої влади, на який законодавством покладено повноваження щодо реалізації адміністративних процедур у зазначеній сфері, - Державна міграційна служба України та її територіальні управління.

Мета статті. Головна мета нашого дослідження - це виявлення найбільш поширених за тематикою позовних вимог у сфері адміністративно-процедурного забезпечення у сфері міграції, тобто тих аспектів діяльності територіальних управлінь ДМС у названій сфері, які найчастіше виступають предметом позову. Інакше кажучи, ми намагатимемося виявити наявність у цій сфері типових адміністративних справ - згідно 3 визначенням КАС України, таких адміністративних справ, відповідачем у яких є один і той самий суб'єкт владних повноважень (його відокремлені структурні підрозділи), спір у яких виник 3 аналогічних підстав, у відносинах, що регулюються одними нормами права, та в яких позивачами заявлено аналогічні вимоги (ч. 21 ст. 4 КАС України) [2].

Важливими критеріями, за якими рішення в адміністративних справах відбираються до нашої дослідницької вибіркової сукупності, є, по-перше, завершеність справи, тобто наявність ухваленої судом постанови. По-друге, враховуючи, 
що, за твердженнями дослідників, адміністративний позов з одного боку й апеляційна та касаційна скарги з іншого є засобами оскарження в різних публічно-правових спорах (у першому випадку - публічно-правового в розумінні ст. 3 КАС України, у другому - процесуально-правового, що виникає у процесі здійснення правосуддя в адміністративних справах) [3, с. 286], до вибіркової сукупності справ, що відповідають нашим дослідницьким завданням, потрапляють справи, розглянуті місцевими та окружними адміністративними судами як судами першої інстанції.

Дещо більш розгорнуто, вважаємо, слід оговорити предмет позову як критерій відбору адміністративних справ для дослідження. Як відомо, сферою міграції адміністративна діяльність підрозділів ДМС не обмежується; до їхньої компетенції віднесено також справи у сфері біженців та осіб, що потребують додаткового або тимчасового захисту, та сфера протидії нелегальній міграції. Необхідно зазначити, що оскарження діяльності ДМС у цих сферах відбувається активніше, ніж оскарження рішень і дій (бездіяльності) у сфері, що становить предмет нашого дослідження. Наприклад, якщо взяти для аналізу справи, датовані 2019 роком, тобто з 1 січня 2019 р. по 31 травня 2019, то у визначений часовий період оскарження діяльності ДМС у сфері протидії нелегальній міграції являє собою абсолютну більшість: загалом за зазначений період, відповідно до даних Єдиного реєстру судових рішень [1], адміністративних справ, відповідачем у яких виступали органи ДМС, налічується 651. При цьому з них 115 справ розглядалися адміністративними судами першої інстанції, 461 справа - судами апеляційної інстанції, 75 - касаційної інстанції; зі 115 справ, що були на розгляді в адміністративних судів першої інстанції, предметом оскарження у 113 випадках були дії щодо затримання та примусового видворення іноземців та осіб без громадянства за межі України; одне рішення (постанова № 80381933) стосувалося скасування органом ДМС посвідки на тимчасове проживання, ще одна постанова (№ 80076876) - вимоги перегляду рішення управління ДМС щодо ненадання особі статусу біженця.

Цей факт, на нашу думку, доводить, що для аналізу предмета нашого дослідження кількісні статистичні методи аналізу є неприйнятними; у нашому випадку слід звернутися до використання якісного методу дослідження кейс-стаді, що зосереджений на аналізі окремих випадків, у нашому випадку окремих адміністративних справ оскарження рішень органів публічної влади в галузі міграції.

Зокрема, стосовно оскарження дій та рішень ДМС у галузі громадянства як типову можемо виділити справу № 2040/5642/18. За даними, викладеними в постанові № 75726182 Харківського окружного адміністративного суду у справі № 2040/5642/18 від 7 серпня 2018 р. [12], позивач звернувся до суду з позовом, в якому висловлено прохання визнати протиправним і скасувати рішення Головного управління Державної міграційної служби України в Харківській області від 28 жовтня 2016 р. про скасування рішення про надання позивачеві громадянства України, а також про визнання паспорта Громадянина України серії № XXX, виданого 16 листопада 2006 р. Печенізьким РВ ГУМВС України в Харківській області на ім'я позивача на підставі довідки № XXX про реєстрацію особи громадянином України, виданої 14 листопада 2006 р. УГІРФО ГУМВС України в Харківській області, відповідно до ст. 24 ЗУ «Про громадянство України» недійсним.
Зі змісту позову випливає, що позивач 16 листопада 2006 р. був документований паспортом громадянина України серії № XXX на підставі довідки про реєстрацію особи громадянином України № XXX, виданої 14 листопада 2006 р. УГІРФО ГУМВС України в Харківській області. До ГУДМС України в Харківській області 3 Головного управління Національної поліції в Харківській області (управління кримінальної поліції) надійшов запит про перевірку осіб, зокрема особи позивача; за результатами проведеної службової перевірки законності набуття позивачем громадянства України складено висновок від 27 жовтня 2016 р. Згідно зі змістом висновку рекомендовано підготувати подання про скасування рішення ГУМВС України в Харківській області від 14 листопада 2006 р. про набуття громадянства України за територіальним походженням відповідно до ч. 1 ст. 8 Закону України від 18 січня 2001 р. «Про громадянство України».

Це Рішення Головного управління Державної міграційної служби України в Харківській області й стало предметом позову.

За рішенням суду, відповідно до ст. 21 Закону України «Про громадянство України» (у редакції на час виникнення спірних правовідносин), рішення про оформлення набуття громадянства України скасовується, якщо особа набула громадянство України, відповідно до ст. ст. 8 та 10 цього Закону, шляхом обману, внаслідок подання свідомо неправдивих відомостей або фальшивих документів, приховування будь-якого суттєвого факту, за наявності якого особа не може набути громадянства України. Однак в оскаржуваному Рішенні за результатами службової перевірки зазначено, що недотримання повною мірою визначеної процедури мало місце саме з боку посадової особи державного органу. Відповідачами не надано доказів і судом не встановлено фактів, які б свідчили про подання позивачем під час оформлення паспорта громадянина України свідомо неправдивих відомостей або фальшивих документів чи приховування позивачем будь-якого суттєвого факту, за наявності якого позивач не мав права набути громадянства України. Відповідач, виявивши допущене порушення процедурних норм посадовою особою державного органу та не довівши жодним чином протиправності дій позивача, встановив негативні наслідки саме для позивача, що є неприпустимим. На підставі викладеного суд дійшов висновку про невідповідність оскаржуваного Рішення приписам ч. 3 ст. 2 КАС України та, відповідно, його протиправність [12].

Подібні справи розглянуто й подібні постанови з визнанням протиправними рішень територіальних управлінь ДМС України щодо скасування попередньо виданих рішень про набуття громадянства України за територіальним походженням винесено Львівським окружним адміністративним судом $[5 ; 6]$, Харківським окружним адміністративним судом [13], Окружним адміністративним судом м. Києва [8] тощо, що дає підстави віднести цю справу до категорії типових. Досить типово виглядають також і дії органів ДМС, що стали причиною оскаржень у судовому порядку: зловживання дискреційними повноваженнями та порушення процедурних норм із боку представників владного органу, внаслідок чого людину фактично позбавляють громадянства, тобто відбувається грубе втручання держави у права, гарантовані Європейською конвенцією з прав людини. Зазначене наводить на думку щодо необхідності окремого розгляду питання стосовно відповідальності органів публічної влади за такі дії. 
У галузі імміграції прикладом типової справи щодо судового оскарження рішень та дій ДМС може послугувати постанова Харківського окружного адміністративного суду від 31 січня 2018 р. № 820/6608/17 [10]. Згідно з матеріалами справи, позивач у порядку адміністративного судочинства заявив вимогу про скасування рішення Управління Державної міграційної служби України в Київській області № 82 від 10 липня 2017 р. про скасування дозволу на імміграцію в Україну громадянину Соціалістичної республіки В'єтнам.

Громадянин В'єтнаму (позивач) прибув в Україну разом iз дружиною у 2002 р.; в Україні в нього народилась дитина, що підтверджується Свідоцтвом про народження, виданим Міським відділом реєстрації актів цивільного стану № 3 Харківського обласного управління юстиції від 28 травня 2006 р. 26 червня 2006 р. позивач звернувся до Васильківського МРВ ГУ МВС України в Київській області з клопотанням про отримання дозволу на імміграцію в Україну як батьку іммігранта на підставі п. 6 ч. 2 ст. 12 Закону України «Про імміграцію», яке було задоволено 4 жовтня 2006 р.

Однак 21 грудня 2017 р. позивачем було отримано копію рішення ГУ ДМС України в Київській області про скасування дозволу на імміграцію в Україну на підставі п. 1,6 ст. 12 Закону України «Про імміграцію» та копію висновку про перевірку законності надання позивачу дозволу на імміграцію. Це рішення й виступило предметом судового оскарження.

Суд, розглянувши спірне рішення та висновок про перевірку законності надання дозволу на імміграцію позивачеві, дійшов висновку, що підставою для прийняття рішення про скасування дозволу на імміграцію в Україну та вилучення посвідки на постійне проживання в Україні стало те, що неповнолітня дитина позивача на момент прийняття документів у іiі батька не мала дозволу на імміграцію, а також не було підтверджено іiі належність до громадянства України.

Перевіряючи відповідність учинених суб'єктом владних повноважень у спірних правовідносинах діянь вимогам КАС України та Закону України «Про імміграцію», суд дійшов висновку, що відповідачем не зазначено, які ж конкретно неправдиві відомості, підроблені документи чи документи, що втратили чинність, були враховані останнім під час прийняття рішення про надання дозволу на імміграцію. Тобто відповідачем в спірному рішенні не визначено фактичної підстави винесеного рішення, а відтак не дотримано правила юридичної визначеності; суду не надано доказів існування підстав для скасування наданого позивачу дозволу на імміграцію.

На підставі зазначеного суд виніс постанову, якою рішення Головного управління Державної міграційної служби України в Київській області від 10 липня 2017 р. № 82 про скасування дозволу позивача на імміграцію в Україну було скасовано [10].

Наявність у Реєстрі аналогічних за предметом позову та вимогами позивачів справ - №№ 820/4847/17 [11], 815/2412/14 [7], 820/4393/17 [9], 495/8188/16-а [4] тощо - дає змогу вважати проаналізовану справу прикладом типової. I знову ж таки за результатами розгляду наведеного кейс-стаді можна зробити висновок, що в діяльності підрозділів ДМС поширеним явищем є прийняття адміністративних рішень на підставі міркувань дискреції, а не законних приписів; порушення, яких припускаються органи публічної влади в адміністративно-процедурній діяльності, обертаються для фізичних осіб, з боку яких жодних порушень скоєно не було, загрозою втрати законних статусів і прав. Таку ситуацію не можна визнати ефективним прикладом правозастосування в галузі адміністративно-процедурного забезпечення сфери міграції.

Враховуючи значущість захисту прав і свобод фізичних осіб як сторони публічно-правових відносин у досліджуваній сфері, слід визнати можливість судового оскарження рішень, дій чи бездіяльності суб'єктів публічної влади в цій сфері важливою гарантією збереження та відновлення індивідуальних прав. У наведених прикладах судові органи виконали цю захисну функцію; для укріплення цієї тенденції раціонально було б скористатися інструментом зразкової адміністративної справи, що стала однією з найбільш очікуваних новел реформування адміністративного судочинства. Згідно з ч. 22 ст. 4 КАС України зразкова справа - це типова адміністративна справа, прийнята до провадження Верховним Судом як судом першої інстанції для постановлення зразкового рішення [9]; інакше кажучи, за допомогою зразкової справи в судову практику впроваджується дієвий процесуальний механізм розгляду справ, схожих за сферою та специфікою правовідносин, у яких виник конфлікт, складом сторін і правових норм, якими вони регулюються, за прикладом рішення Верховного Суду в одній з таких справ, тобто за зразковою справою [14]. Сподіваємося, що наші аналітичні кейс-стаді можуть послугувати скромним дослідницьким внеском у підготовчу роботу Касаційного адміністративного суду до визначення справ, що можуть бути визнані зразковими.

Отже, адміністративне оскарження, незважаючи на ознаку факультативності, $є$ важливим етапом адміністративної процедури у сфері міграції. 3 одного боку, оскарження призначене на виявлення й усунення недоліків у практичній процедурній діяльності органів публічної влади у сфері міграції; з іншого сприяє вдосконаленню самої процедурної моделі вирішення індивідуальних справ у досліджуваній сфері, виявляючи іiі дефекти і слабкі місця. Законодавче закріплення можливості здійснення оскарження в судовому та адміністративному порядку зумовлює наявність двох форм оскарження - адміністративно-процедурної та адміністративно-процесуальної, що в сукупності створюють гарантійний інструмент захисту прав приватних осіб на громадянство та на свободу пересування й вільний вибір місця проживання.

\section{Лimepamypa:}

1. Єдиний державний реєстр судових рішень. URL: http://reyestr.court.gov.ua.

2. Кодекс адміністративного судочинства України № 2747-IV у ред. від 14 червня 2018 p. URL: http://zakon.rada.gov.ua/laws/ show/2747-15.

3. Лученко Д.В. Скарга як процесуальна форма правозахисту в адміністративно-правових відносинах. Вісник Національного університету «Юридична академія Украӥни імені Ярослава Мудрого». Серія: Економічна теорія і право. 2014. № 1. С. 285-294.

4. Постанова Білгород-Дністровського міськрайонного суду Одеської області № 62889557 від 16 листопада 2016 р. у справі № 495/8188/16-a. Єдиний державний реєстр судових рімень. URL: http://reyestr.court.gov.ua/Review/62889557.

5. Постанова Львівського окружного адміністративного суду № 76937587від 27 вересня 2018 р. у справі № 813/1773/18. Сдиний державний реєстр судових рімень. URL: http://reyestr.court.gov.ua/ Review/76937587.

6. Постанова Львівського окружного адміністративного суду № 78579611 від 6 грудня 2018 р. у справі № 1340/4210/18. Сдиний державний реєстр судових рімень. URL: http://reyestr.court.gov.ua/ Review/78579611. 
7. Постанова Одеського окружного адміністративного суду № 38702331 від 13 травня 2014 р. у справі № 815/2412/14. Сдиний державний реєстр судових рішень. URL: http://reyestr.court.gov.ua/ Review/38702331.

8. Постанова Окружного адміністративного суду м. Київ № 65436770 від 21 березня 2017 р. у справі № 826/18401/14. Єдиний державний реєстр судових рімень. URL: http:// reyestr.court.gov.ua/Review/65436770.

9. Постанова Харківського окружного адміністративного суду № 69794626 від 25 жовтня 2017 р. у справі № 820/4393/17. Сдиний державний реєстр судових рімень. URL: http://reyestr.court.gov.ua/ Review/69794626.

10. Постанова Харківського окружного адміністративного суду № 71934231 від 31 січня 2018 р. у справі № 820/6608/17. Єдиний державний реєстр судових рімень. URL: http:// www.reyestr.court.gov.ua/Review/71934231.

11. Постанова Харківського окружного адміністративного суду № 71934231 від 14 листопада 2017 р. у справі № 820/4847/17. Єдиний державний реєстр судових рімень. URL: http:// reyestr.court.gov.ua/Review/70211618.

12. Постанова Харківського окружного адміністративного суду № 75726182 від 7 серпня 2018 р. у справі № 2040/5642/18. Єдиний державний реєстр судових рімень. URL: http://reyestr.court.gov.ua/ Review/75726182.

13. Постанова Харківського окружного адміністративного суду № 78189637 від 28 листопада 2018 р. у справі № 520/9237/18. Єдиний державний реєстр судових рімень. URL: http:// reyestr.court.gov.ua/Review/78189637.

14. Савчук М. Типові та зразкові справи за новим КАСУ. Юридична газета: всеукраїнське щотижневе професійне юридичне видання. URL: http://yur-gazeta.com/dumka-eksperta/zrazkove-sudochinstvotipovi-ta-zrazkovi-spravi-za-novim-kasu.html.

Yermakov Yu. Judicial procedure for appealing against decisions, actions or omissions of the authorities regarding the implementation of administrative procedures in the field of migration

Summary. A scholarly article is devoted to the litigation of appealing against decisions, actions or omissions of public administration entities regarding the implementation of administrative procedures in the field of migration. Administrative appeals have been found to be an important stage of the administrative procedure in the field of migration, despite the sign of optionality. On the one hand, the appeal is intended to identify and remedy deficiencies in the practical procedural activities of public authorities in the field of migration; on the other, it contributes to the improvement of the procedural model of solving individual cases in the investigated sphere, revealing its defects and weaknesses.

Emphasis is placed on the legislative consolidation of the possibility of appealing throughjudicial and administrative procedures, which leads to the existence of two forms of appeal - administrative procedural and administrative procedural, which together create a guarantee instrument for protecting the rights of individuals for citizenship and freedom of residence and free choice of place of residence.

It is established that the presence in the Register on the subject of the claim and the requirements of the claimants Nos. 820/4847/17, 815/2412/14, 820/4393/17, 495/8188/16-a, etc. - allows to consider the analyzed case as an example. Again, the results of the consideration of the above casestudy suggest that administrative decision-making on the basis of discretion, rather than lawful prescriptions, is common in the activities of the LCA, violations committed by public authorities in administrative and procedural activities are rotated for individuals, from whom no violations have been committed, threatening to lose their legal status and rights. This situation cannot be recognized as an effective example of enforcement in the area of administrative and procedural support for migration.

Given the importance of protecting the rights and freedoms of individuals as a party to public-law relations in the research area, the possibility of judicial appeals against decisions, actions or omissions of public authorities in this field should be recognized as an important guarantee for the preservation and restoration of individual rights. In the above examples, the judicial authorities have fulfilled this protective function; to reinforce this tendency it would be rational to use the instrument of exemplary administrative case, which has become one of the most anticipated innovations in the reform of administrative justice. According to Part 22 of Art. 4 CAS of Ukraine is an exemplary administrative case, which is a typical administrative case, adopted before the Supreme Court as a court of first instance for issuing an exemplary decision; in other words, through an exemplary case, a judicial procedural mechanism introduces an effective procedural mechanism for dealing with cases similar in scope and specifics of conflicts in the conflict, the composition of the parties and the legal rules they regulate, following the example of a Supreme Court decision in one such case, that is, an exemplary case.

Key words: administrative procedure, inactivity, stages, actions, immigration, stage, court procedure, appeals. 